\title{
Forecasting the conditional heteroscedasticity of stock returns using asymmetric models based on empirical evidence from Eastern European countries: Will there be an impact on other industries?
}

DOI: $10.35530 / I T .072 .03 .202042$

\author{
ELIZABETH COKER-FARRELL \\ ZULFIQAR ALI IMRAN \\ CRISTI SPULBAR
}

ABDULLAH EJAZ

RAMONA BIRAU

RADU CĂTĂLIN CRIVEANU

\begin{abstract}
REZUMAT
Forecasting the conditional heteroscedasticity of stock returns using asymmetric models based on empirical evidence from Eastern European countries: Will there be an impact on other industries?

This empirical study investigates the leverage effect in six Eastern European countries under normal and non-normal distribution densities for the sample period from January 2020 to August 2020. We find three countries, Bulgaria, Czech Republic and Russia which are subject to ARCH effect whereas Poland, Romania and Hungary do not exhibit $\mathrm{ARCH}$ effect in daily stock returns. Further, our study finds leverage effect, where past bad news affects is asymmetrical, past negative returns cause more volatility in current stock returns as compared to past positive returns, in three Eastern European countries. Based on the AIC and BIC model selection criteria we find that the non-normal student t-distribution and GED produce reliable estimates for Bulgaria, Czech Republic and Poland, respectively. The autocorrelation function Q1 statistic confirms the insignificance of autocorrelation in residuals of TGARCH model. The impact of stock market dynamics on other industries, such as pharmaceutical industry, textile and clothing industry, automotive industry is significant, especially in the conditions of COVID-19 pandemic.
\end{abstract}

Keywords: stock market, Eastern European countries, TGARCH model, leverage effect, return

Predicția heteroscedasticității condiționate a randamentelor acțiunilor utilizând modele asimetrice bazate pe cercetări empirice privind țările din Europa de Est: va exista oare un impact asupra altor industrii?

Acest studiu empiric investighează efectul de levier la nivelul a șase țări din Europa de Est în cazul distribuției normale, precum și a distribuţiei care nu este normală, pentru perioada de eșantionare din ianuarie 2020 până în august 2020. Rezultatele empirice identifică trei țări, și anume: Bulgaria, Cehia și Rusia care sunt supuse efectului ARCH în timp ce Polonia, România și Ungaria nu prezintă efect ARCH în cazul rentabilităților zilnice. Mai mult, studiul nostru constată existența unui efect de levier, în cazul în care impactul știrilor negative din trecut este asimetric, randamentele negative din trecut cauzează mai multă volatilitate a randamentelor actuale ale actiunilor în comparatie cu randamentele pozitive din trecut, în trei dintre țările din Europa de Est selectate. Pe baza criteriilor de selecție a modelelor AIC și BIC, constatăm că distributia t-Student care nu este normală și GED produc estimări fiabile pentru Bulgaria, Cehia și Polonia. Impactul dinamicii pieței bursiere asupra altor industrii, cum ar fi industria farmaceutică, industria textilă și a îmbrăcămintei, industria auto, este semnificativ, în special în condițiile pandemiei COVID-19.

Cuvinte-cheie: piață bursieră, țări din Europa de Est, model TGARCH, efect de levier, rentabilitate

\section{INTRODUCTION}

The year 2020 was a major challenge for all countries in the world in the context of the COVID-19 pandemic. The selected European states are no exception. Most industrial sectors were affected, production was significantly reduced or even stopped, many employees lost their jobs, thus increasing the unemployment rate, global demand collapsed, consumption was severely limited, while global economy experienced significant disturbances. For example, the textile and clothing industry has been severely affected by the pandemic crisis. People were more interested in providing for essential necessities such as food, water, hygiene products, pharmaceuticals and medicines. Moreover, Europe's lockdown negatively influenced the sales volume as well as the production level. As a direct consequence, many companies have gone bankrupt. According to Tudor [1] textile and clothing industry is distinguished by its incremental changes but the current global business environment creates the premises of multiple organizational disruptive changes. On the other hand, cotton represents one of the most commonly used textile fibres in the world [2]. However, in the context of the COVID-19 pandemic, the textile industry refocused on the design of face masks or sanitary materials. In this extremely turbulent context, financial investments and stock market behaviour are essential in mitigating the effects of the pandemic on the economy.

In case of financial time series data, leptokurtosis and volatility clustering are commonly observed phenomenon that indicates the higher level of risk 
involved [3]. There is one more measure, leverage effect that has acquired great attention that inculcates the fluctuation in security prices are inversely correlated to the fluctuation in security's own volatility. Characteristically, a rising stock price is accompanied by the decline in volatility and vice versa. The term "leverage" refers to one possible economic interpretation of this phenomenon, developed by Black [4] and Christie [5]: as stock prices fall, companies become more leveraged because the relative value of their debt rises relative to that of their equity. As a result, it is common to believe that their stock have become riskier, hence more volatile. While this is only a hypothesis, but it is widely believed in financial literature that the term "leverage effect" refers to describe a statistical regularity in question. It has also been documented that the effect is generally asymmetric: other things equal, declines in stock prices are accompanied by larger increases in volatility than the decline in volatility that accompanies rising stock markets $[6,7]$. To encounter these types of risks in financial time series data require to use wide variety of models that incapsulate varying variance to estimate current and predict future volatility.

Engle [8] has proposed Autoregressive Conditional Heteroskedasticity $(\mathrm{ARCH})$ model that is based on conditional time varying variance which considers the lagged disturbance. (It models the change in variance over time in financial time series data).

Whereas the extension of $\mathrm{ARCH}$ model is proposed by Bollerslev [9], Generalized Autoregressive Conditional Heteroskedasticity (GARCH) model, that includes the higher order ARCH model to capture the dynamic behaviour of conditional variance. Although $\mathrm{ARCH}$ and $\mathrm{GARCH}$ models encounter leptokurtosis and volatility clustering due to symmetric distribution, however, fail to incapsulate leverage effect in financial time series data. To estimate the leverage effect, some non-linear extensions of GARCH model has been proposed, for instance, EGARCH [6], GJR [10] and asymmetric power ARCH (APARCH) [11].

Another drawback of GARH model is lack of embracing thick tail property of high frequency of financial time series. Bollerslev [12] and Baillie and Bollerslev [13] have provided the solution to this problem through using student's t-distribution. Furthermore, Liu and Brorsen [14] used asymmetric stable density to captures skewness. In order to model kurtosis and skewness Fernandez and Steel [15] supported skewed student's t-distribution that later on Lambert and Laurent $[16,17]$ incorporate this into $\mathrm{GARCH}$ framework. To make GARH and EGARCH model fit for stock markets, Harris et al. [18] use skewed generalized student's t-distribution to estimate skewness and leverage effect of daily stock returns.

Despite an extensive amount of research on symmetric and asymmetric GARCH models, less attention has been drawn to compare alternative density forecast model specially in the context of Eastern European stock markets after Drachal [19]. The financial time series data especially stock returns are mostly high-frequency data which means that stock returns are subject to fat-tailed distribution. It is wellknown fact in finance literature that the stock returns mostly experience kurtosis higher than 3 [20, 21]. Kurtosis greater than 3 ascertains that stock returns are characterised by extreme returns than the normal distribution. Mittnik and Paolella [22] have argued that fat-tailed distribution density is important to model in the daily exchange rate of merging countries' currencies against dollar.

In this study we fill the gap by using normal distribution density (Gaussian) and non-normal distribution densities (Student's t-distribution and Generalized Error Distribution (GED)) to evaluate leverage effect in case of selected stock markets. In this discourse, we will explore whether change in distributional densities under ARCH, GARCH and TGARCH models leads to any substantial change in volatility and leverage effect. We will also explore the portfolio diversification opportunities in Eastern European countries and estimate the forecasts. We employ volatility model to test its ability to forecast and capture the volatility clustering, leptokurtosis and impact of negative vs positive stock returns (leverage effect) in financial time series data. We investigate the forecasting ability of $\mathrm{ARCH}, \mathrm{GARCH}$ and TGARCH model with the use of normal and non-normal distributional densities.

\section{DATA AND RESEARCH METHODOLOGY}

This section discusses the data and methodology approach to estimate the leverage effect using TGARCH model and compares the three different densities under GARCH and TGARCH models.

\section{Data}

We selected six stock market indices daily data from Eastern European stock markets namely, Bulgaria (BSE SOFIX), Czech Republic (PX), Hungary (BUDAPEST SE as BUX index), Poland (WIG) Romania (BETI as BET index) and Russia (MOEX) from January 2020 to August 2020 by collecting data from websites, such as www.investing.com. We compute the returns of these six indices through following formula:

$$
r_{i t}=\ln \left(\frac{p_{i t}}{p_{i t-1}}\right) \cdot 100
$$

where $r_{i t}$ is the compounded returns of stock $i$ at time $t, p_{i t}$ - current prices of stock $i$ in $t$ time and $p_{i t-1}-$ previous year prices of stock $i$ in $t$ time. Table 1 provides the descriptive statistics, test for normality and the presence of $\mathrm{ARCH}$ effect. It can be observed that all six countries exhibit negative mean returns. Trivedi et al. [23] pointed out that modelling the behaviour of European stock markets represents a current challenge of great interest. Hungary stock index is riskier followed by Poland and Russia as indicated by the unconditional standard deviation. The negative skewness estimates confirm that the distribution of all six countries is negatively skewed. The null hypothesis for skewness that conforms to a 


\begin{tabular}{|l|c|c|c|c|c|c|}
\hline \multicolumn{7}{|c|}{ DESCRIPTIVE STATISTICS OF DAILY INDICES RETURNS } \\
\hline \multicolumn{1}{|c|}{ Countries } & Bulgaria & Czech Republic & Hungary & Poland & Romania & Russia \\
\hline Mean & -0.1869 & -0.1354 & -0.1654 & -0.0845 & -0.0981 & -0.0258 \\
\hline Median & -0.0787 & -0.0406 & -0.0389 & 0.0023 & 0.0814 & 0.1631 \\
\hline Standard Deviation & 1.5075 & 1.9138 & 2.2391 & 2.1760 & 1.9271 & 1.9646 \\
\hline Max & 3.9533 & 7.3691 & 5.6286 & 5.6337 & 5.9726 & 7.4349 \\
\hline Min & -10.8104 & -8.1605 & -12.2684 & -13.5265 & -10.0753 & -8.6460 \\
\hline Skewness & -3.384 & -0.8797 & -1.3919 & -1.7974 & -1.2970 & -0.7814 \\
\hline Kurtosis & 23.869 & 7.9337 & 9.3687 & 12.7027 & 9.6812 & 8.9648 \\
\hline Jarque-Bera Test & 0.000 & 0.000 & 0.000 & 0.000 & 0.000 & 0.000 \\
\hline ARCH (1), Chi2 > Prob & 0.2436 & 0.3206 & 0.0111 & 0.0305 & 0.0063 & 0.2313 \\
\hline Observation & 148 & 152 & 152 & 152 & 149 & 148 \\
\hline
\end{tabular}

normal distribution with coefficients of zero has been rejected for all six indices. The returns for six indices also exhibit fat tail as seen in the significant kurtosis well above the normal value of 3 . The higher value of Kurtosis, fat-tailed distribution density, indicates that Student's t-distribution or GED are more accurate distribution and produce better results than Gaussian distribution. Jarque-Bera test of normality shows the residuals are not normally distributed at 1 percent level of significance. Finally, Engle [8] LM test confirms the presence of ARCH effect in Bulgaria, Czech Republic and Russia whereas Hungary, Poland and Romania are not subject to ARCH effect. Hence, this supports the use of GARCH and TGARCH models for the countries where ARCH effect is significant.

Measuring the volatility through $A R C H, G A R C H$ and TGARCH model

Spulbar et al. [24] suggested that emerging stock markets reacts much more intense in case of positive or negative news impact compared to developed stock markets. It is also observed that large positive (negative) observations mostly appear in clusters in stock returns [25]. Thus, linear estimation techniques (OLS) are incapable of explaining the number of important features that are common the stock daily returns.

- Leptokurtosis - Stock daily returns experience fattailed distribution.

- Volatility Clustering - The tendency to stock returns volatility that appears in clusters in stock returns. For example - the large returns of stocks, either sign, are followed by large returns and small returns of stock, either sign, are expected to have small returns in the following period. One of the explanations to volatility clustering is that the arrival of information that creates volatility clustering in the stock returns.

- Leverage effect - the likelihood of volatility to increase more following the large dip in the prices, compared to the price rise of the magnitude.
The Autoregressive Conditional Heteroscedasticity model (ARCH)

Constant variance (homoscedasticity) is one of most important assumptions of classical regression model: $\operatorname{var}\left(\mu_{t}\right)=\sigma^{2}\left(\mu_{t}\right), \mu_{t} N\left(0, \sigma^{2}\right)$. A series with changing variance over time is characterized as heteroscedastic which is very likely in financial time series data. Such financial series require an estimator that does not assume that error term possesses constant variance and moreover, it should also ascertain that how error term variance evolves over time.

Another problem with time series financial data is volatility clustering, meaning that the period of high volatility is followed by higher volatility period and period of low volatility is characterized with period of lower volatility. Using ARCH model, the time series financial data with non-constant variance in error term can be parameterized. It is also necessary to define a conditional variance of error term $\mu_{t}$ in order to understand how ARCH model works. The conditional variance of $\mu_{t}$ is represented by $\sigma^{2}$ as follows:

$$
\sigma_{t}^{2}=\operatorname{var}\left(\mu_{t} \mid \mu_{t-1}, \mu_{t-1} \ldots\right)=E
$$

According to equation 2 a conditional variance of zero mean random variable $\mu_{t}$ that is normally distributed is equal to the conditional expected value of the square of $\mu_{t}$. In such a situation ARCH model is as follows:

$$
\sigma_{t}^{2}=\alpha_{0}+\alpha_{1}+\mu_{t}^{2}
$$

Equation 5 is an ARCH (1) model which shows that conditional variance of error term $\sigma_{t}^{2}$ is influenced by its immediate previous square root value. However, it should be noted that equation 5 only ascertains the part of complete model because it does not have anything to say about conditional mean. The conditional mean equation, where dependent variable $\mathrm{Y}_{t}$ changes over time can take any form under $\mathrm{ARCH}$ model. The full ARCH model is as follows:

$$
\begin{gathered}
\mathrm{Y}_{t}=\beta_{1}+\beta_{2} x_{2 t}+\beta_{3} x_{3 t}+\beta_{4} x_{4 t}+\mu_{t} \\
\sigma_{t}^{2}=\alpha_{0}+\alpha_{1} \mu_{t-1}^{2}
\end{gathered}
$$

where $\mu_{t} N\left(0, \sigma^{2}\right)$. 
Equations 4 and 5 can also be expressed in general form where variance of an error term is influenced by $k$ lags of square errors. This type of model is called $\operatorname{ARCH}(k)$.

$$
\begin{gathered}
\mathrm{Y}_{t}=\beta_{1}+\beta_{2} x_{2 t}+\beta_{3} x_{3 t}+\beta_{4} x_{4 t}+\mu_{t} \\
\sigma_{t}^{2}=\alpha_{0}+\alpha_{1} \mu_{t-1}^{2}+\alpha_{2} \mu_{t-2}^{2}+\ldots+\alpha_{k} \mu_{t-k}^{2}
\end{gathered}
$$

where $\mu_{t} N\left(0, \sigma^{2}\right) . \sigma_{t}^{2}$ is a conditional variance where it have positive value (a negative variance at any time is meaningless) which mean that the variance regression must produce positive coefficients, for instance $\alpha_{i} \geq 0,(\forall) i=0,1,2, \ldots, k$. GARCH is the extension of $\mathrm{ARCH}(k)$ model.

The Generalized Introgressive Conditional Heteroscedastic Model (GARCH)

The GARCH model, developed by Bollerslev [9] and Taylor [26] estimate conditional variance that is influenced by it only previous lagged values. Following equation is an example of conditional variance.

$$
\sigma_{t}^{2}=\alpha_{0}+\alpha_{1} \mu_{t-1}^{2}+\beta \sigma_{t-1}^{2}
$$

Equation 8 is a $\operatorname{GARCH}(1,1)$ model where $\alpha_{1} \mu_{t-1}^{2}$ express the information of volatility pertaining to previous period and variance during that period $\beta \sigma_{t-1}^{2}$. GARCH(1/1) model can also be written in a GARCH $(k, p)$ form where conditional variance is influenced by $k$ lags of squared errors and $p$ lags of conditional variances.

$$
\begin{aligned}
\sigma_{t}^{2}= & \alpha_{0}+\alpha_{1} \mu_{t-1}^{2}+\alpha_{2} \mu_{t-2}^{2}+\ldots+\alpha_{k} \mu_{t-k}^{2}+ \\
& +\beta_{1} \sigma_{t-1}^{2}+\beta_{2} \sigma_{t-2}^{2}+\ldots+\beta_{p} \sigma_{t-p}^{2}
\end{aligned}
$$

Equation 10 can be rearranged as:

$$
\sigma_{t}^{2}=\alpha_{0}+\sum_{i=1}^{k} \alpha_{i} \mu_{t-i}^{2}+\sum_{j=1}^{p} \beta_{j} \sigma_{t-j}^{2}
$$

$\operatorname{GARH}(1,1)$ model is mostly estimated and sufficient to estimate the evolution of volatility as $\operatorname{GARH}(1,1)$ model is as good as $\operatorname{ARCH}(2)$ and $\operatorname{GARCH}(k, p)$ is as good as $\mathrm{ARCH}(k+p)$ model [25].

The Threshold Generalized Introgressive Conditional Heteroscedastic Model (TGARCH)

The Threshold GARCH (TGARCH) model was presented by Glosten et al. [27] which is also called GJR-GARCH (after its proponents). This model is similar to simple GARCH model but adds an additional $\mathrm{ARCH}$ term which is conditional upon the direction of the past information or innovation. It is specified as follows:

$$
\begin{gathered}
\sigma_{t}^{2}=\alpha_{0}+\beta_{1} \sigma_{t-1}^{2}+\alpha_{1} \mu_{t-1}^{2}+\lambda_{1} \mu_{t-1}^{2} d_{t-1} \\
d_{t}=\left\{\begin{array}{l}
1 \mu_{t}<0 \text { (BadNews) } \\
0 \mu_{t} \leq 0 \text { (GoodNews) }
\end{array}\right.
\end{gathered}
$$

Equation $11, \lambda_{1}$ estimates the leverage effect and $d_{t}$ is the dummy variable which present 1 if $\mu_{t}$ is negative. If stock returns are characterized with leverage effect, the value of $\lambda_{1}$ should be negatively significant.

\section{Density distributions}

The GARCH model use Maximum Likelihood Estimation (MLE) which assumes that error distribution is Gaussian (normally distributed), nevertheless, financial literature is evident that error is subject to non-normal distribution densities [6]. It is an of utmost importance to select the most appropriate distribution for error term during volatility modelling because it reduces the problem posed by skewness and kurtosis due to residuals of conditional heteroscedasticity. Hence, our study employs all three form of distributions, Gaussian, Students' t-distribution and Generalised Error Distribution and compare the results.

\section{Gaussian}

The Gaussian distribution, which is also called normal distribution, is most widely used distribution when estimating GARCH models. For a stochastic process, it is important the log-likelihood function.

\section{Student T-Distribution}

The log likelihood function for non-normal distribution as follows:

$$
\begin{gathered}
L_{s t u-t}=\ln \left(T\left[\frac{v+1}{2}\right]\right)-\ln \left(7 \frac{v}{2}\right)-\frac{1}{2} \ln (\pi[v-2])- \\
\quad-\frac{1}{2} \sum_{t-1}^{T}\left(\ln \sigma_{t}^{2}+[1+v] \ln \left[1+\frac{z_{t}^{2}}{v-2}\right]\right)
\end{gathered}
$$

where degree of freedom is " $v$ ", $2<v=\infty$, and $T($.$) is$ the gamma function.

\section{Generalised Error Distribution (GED)}

Asset pricing, option pricing, portfolio selection, VAR, skewness and Kurtosis are very important in applied finance field. The GED distribution represents a generalised form of the Gaussian that has a parametric kurtosis that is unbounded above and has special cases that are identical to the normal and property which controls the skewness. The log likelihood function is as follows:

$$
\begin{aligned}
L_{G E D}=\sum_{t-1}( & \ln \left[\frac{v}{\lambda_{v}}\right]-0.5\left|\frac{z_{t}}{\lambda_{v}}\right|-\left[1+v^{-1}\right] \ln 2- \\
& \left.-\ln 7\left[\frac{1}{v}\right] 0.5 \ln \left[\sigma_{t}^{2}\right]\right)
\end{aligned}
$$

where $\lambda_{v}=\sqrt{7}$.

\section{EMPIRICAL RESULTS AND DISCUSSION}

This section interprets the empirical results and provides insight into the estimations using $\mathrm{GARCH}$ and TGARCH models under three different distribution densities.

Table 2 reports the statistics pertaining to the use of asymmetric TGARCH model using normal Gaussian, normal distribution density, Student's t-distribution and generalized error distribution (GED), abnormal distribution densities, for six indices, Bulgaria, Czech Republic, and Poland where Arch effect is present as shown in table 1. Table 2 also provides diagnostic test by estimating the values of $\mathrm{AIC}$ and $\mathrm{BIC}$ (Akaike's information criterion and Bayesian information criterion) to compare the results of TGARCH 


\begin{tabular}{|c|c|c|c|c|c|c|c|c|c|}
\hline \multicolumn{6}{|c|}{ ESTIMATED STATISTICS-COMPARATIVE DISTRIBUTION DENSITY THRESHOLD-GARCH MODEL } \\
\hline Country & \multicolumn{3}{|c|}{ Bulgaria } & \multicolumn{3}{c|}{ Czech Republic } & \multicolumn{3}{c|}{ Poland } \\
\hline Parameter & Gaussian & $\begin{array}{c}\text { Student's } \\
\text { t-distribution }\end{array}$ & GED & Gaussian & $\begin{array}{c}\text { Student's } \\
\text { t-distribution }\end{array}$ & GED & Gaussian & $\begin{array}{c}\text { Student's } \\
\text { t-distribution }\end{array}$ & GED \\
\hline & -0.0184 & $0.1355^{* *}$ & 0.0429 & $-1.498^{* *}$ & -0.557 & -0.998 & 0.3496 & 0.4396 & 0.3997 \\
\hline & $0.509^{* * *}$ & 0.1267 & 03873 & $1.2903^{* * *}$ & $0.935^{* * *}$ & $1.1055^{* * *}$ & $0.4948^{* * *}$ & $0.4311^{* * *}$ & $0.4635^{* *}$ \\
\hline & $2.463^{* * *}$ & $1.912^{* * *}$ & $1.989^{* * *}$ & $0.2098^{* *}$ & $0.3802^{* *}$ & $0.2889^{*}$ & $1.0571^{* * *}$ & $1.032^{* * *}$ & $0.9331^{* * *}$ \\
\hline & $-2.081^{* * *}$ & $-1.656^{* * *}$ & $-1.669^{* * *}$ & -0.1473 & $-0.309^{*}$ & -0.2109 & $-0.9959^{* * *}$ & $-0.9458^{* * *}$ & $-0.5313^{* * *}$ \\
\hline AIC & 471.27 & 387.97 & 481.43 & 600.13 & 581.54 & 582.96 & 560.85 & 555.89 & 555.33 \\
\hline BIC & 486.25 & 402.96 & 433.42 & 615.25 & 596.66 & 598.08 & 575.84 & 570.78 & 570.32 \\
\hline Q1 & 0.0041 & 0.0041 & 0.0041 & 2.2947 & 2.2947 & 2.2947 & 0.6771 & 0.6771 & 0.6771 \\
\hline
\end{tabular}

Note: Table 2 shows the estimate of ARCH, GARCH and TGARCH model under normal (Gaussian)and non-normal distribution (Student t-distribution and GED) along with model selection criteria (AIC and BIC). Further table 2 shows autocorrelation in residuals on lag one pertaining to each distribution.

model under normal and non-normal distribution densities. The evidence shows that ARCH effect $\alpha_{1}$ is significant at $1 \%$ level across in all six countries under normal and non-normal distribution density. This implies that past stock returns information can influence the current stock returns across all three countries. Analogously, the coefficient of $\mathrm{GARCH}$ effect $\beta_{1}$ is also significant at $1 \%$ for all three countries, except for Bulgaria under non-normal distributions, under normal and non-normal distribution densities. Positive significant $\beta_{1}$ states that past volatility of stock returns influences the present-day volatility of stock returns.

Moreover, the impact of news $\lambda_{1} \neq 0$ is significant in Bulgaria and Poland that indicates the previous day negative stock returns (bad news) have greater impact of present-day stock returns volatility as compared to positive volatility (good news). On the other hand, $\lambda_{1}=0$ for Czech Republic under normal and abnormal distribution densities establishes the insignificance of leverage effect in Bulgaria and Poland. The leverage effect $\lambda_{1}$ is more profound in the case of Bulgaria than Poland. Under normal distribution densities are similar to Gaussian distribution. However, magnitude further falls when apply non-normal distribution. Thus, results indicate that in Bulgaria and Poland experience the leverage effect, where bad news does generate higher volatility than good news. The model selection criteria AIC and BIC suggest that non-normal distribution student $t$-distribution and GED produce more reliable results for Bulgaria and Poland, respectively.

\section{CONCLUSIONS}

The aim of the study is to evaluate and forecast the performance of asymmetric volatility (leverage effect) through TGARCH model under normal and non-normal distribution densities and then second, to explore the possible opportunities for portfolio diversification in African countries, South Africa, Nigeria and Egypt.
Our study contributes to the existing literature as follows, first we select emerging stock market from Africa where such study has not been done yet. Second, we model asymmetric volatility of individual stock market as well as diversified portfolio and capture time series feature of kurtosis, skewness and volatility clustering. Third, we introduce the comparison among normal and non-normal distribution density of asymmetric model across all three countries. Our results show that all six countries have leptokurtic (fat tail) and negative skewed distribution. TGARCH model for individual country shows that past stock returns (volatility) influence the current stock returns (volatility) across all countries under all distribution densities, whereas, leverage effect is only present in Bulgaria and Poland and negative returns do generate higher volatility as compare the positive returns. On the other hand, leverage effect is insignificant in Czech Republic. The diagnostic tests show $\mathrm{AIC}$ and $\mathrm{BIC}$ produce lowest estimates under student t-distribution for Bulgaria and GED for Poland. This infers that non-normal distribution produces better and reliable estimates for all countries.

The presence of ARCH effect suggests that investors in these markets should seek more information about volatility before allocating their funds for portfolio investment, fund managers and/or investors should go beyond the mean-variance analysis in regards to these markets and look into information about volatility, information asymmetry, correlation, but also skewness and kurtosis which measures the peakedness or flatness of

the distribution, i.e. leptokurtic distribution [28]. Cost of equity capital is expected to be high in these markets due to compensation for additional $\mathrm{ARCH}$ effect which places additional burden on indigenous in all six countries.

Finally, there are areas where further studies might be useful. We recommend that future research be directed at modelling and forecasting realised volatility from intra-day trading data. We will also consider 
the fact that COVID-19 pandemic has spread globally and affected economies around the world since January 2020 [29]. Furthermore, future research may also consider exploring a variety of models including other conditional variance models such as APARCH and long memory models such as FIEGARCH,
FIAPARCH and CGARCH in order to allow a superior insight into the dynamics of these market series. Lastly the study should be replicated in other European countries in order to shed more light on the economic and structural variables that drive volatility in Eastern European stock markets.

\section{REFERENCES}

[1] Tudor, L., Change in Textile and Clothing Industry, In: Industria Textila, 2018, 69, 1, 37-43, http://doi.org/10.35530/IT.069.01.1449

[2] Mengüç, G.S., Dalbaşi, E.S., Özgüney, A.T., Özdil, N.,A comparative study on handle properties of bamboo and cotton fabrics, In: Industria Textila, 2019, 70, 3, 278-284, http://doi.org/10.35530/IT.070.03.1538

[3] Mandelbrot, B., The variation of certain speculative prices, In: Journal of Business, 1963, 36, 394-419

[4] Black, F.,Studies of stock price volatility changes, In:Proceedings of the 1976 Meetings of the American Statistical Association. Business and Economics Statistics Section, 1976, 177-181

[5] Christie, A.A., The stochastic behavior of common stock variances: Value, leverage and interest rate effects, In: Journal of financial Economics, 1982, 10, 4, 407-432

[6] Nelson, D.B.,Conditional heteroskedasticity in asset returns: A new approach, In: Econometrica: Journal of the Econometric Society, 1991, 347-370

[7] Engle, R.F., Ng, V.K.,Measuring and testing the impact of news on volatility, In: The journal of finance, 1993,48, 5, 1749-1778

[8] Engle, R.F., Autoregressive conditional heteroscedasticity with estimates of the variance of United Kingdom inflation, In: Econometrica: Journal of the Econometric Society, 1982, 987-1007

[9] Bollerslev, T., Generalized autoregressive conditional heteroskedasticity, In: Journal of econometrics, 1986, 31, 3, 307-327

[10] Glosten, L.R., Jagannathan, R., Runkle, D.E., On the relations between the expected value and the volatility of the nominal excess returns on stocks, In:Journal of Finance, 1993, 48, 5, $1779-1801$

[11] Ding, Z., Granger, C.W., Engle, R.F.,A long memory property of stock market returns and a new model, In: Journal of empirical finance, 1993, 1, 1, 83-106

[12] Bollerslev, T.,A conditionally heteroskedastic time series model for speculative prices and rates of return, In: The review of economics and statistics, 1987, 542-547

[13] Baillie, R.T., Bollerslev, T.,Common stochastic trends in a system of exchange rates, In: The Journal of Finance, 1989, 44, 1, 167-181

[14] Liu, S.M., Brorsen, B.W., GARCH-stable as a model of futures price movements, In: Review of Quantitative Finance and Accounting, 1995, 5, 2, 155-167

[15] Fernández, C., Steel, M.F.,On Bayesian modeling of fat tails and skewness, In: Journal of the American Statistical Association, 1998, 93, 441, 359-371

[16] Lambert, P., Laurent, S.,Modelling skewness dynamics in series of financial data, Institut de Statistique, 2000

[17] Lambert, P., Laurent, S.,Modelling financial time series using GARCH-type models with a skewed student distribution for the innovations, No. UCL-Université Catholique de Louvain, 2001

[18] Harris, R.D., Coskun Küçüközmen, C., Yilmaz, F.,Skewness in the conditional distribution of daily equity returns, In: Applied Financial Economics, 2004, 14, 3, 195-202

[19] Drachal, K., Volatility clustering, leverage effects and risk-return tradeoff in the selected stock markets in the CEE countries, In: ESPERA, 2017, 20, 3

[20] Simkowitz, M.A., Beedles, W.L., Asymmetric stable distributed security returns, In: Journal of the American Statistical Association, 1980, 75, 370, 306-312

[21] Kon, S.J.,Models of stock returns - a comparison, In: The Journal of Finance, 1984, 39, 1, 147-165

[22] Mittnik, S., Paolella, M.S., Rachev, S.T., Stationarity of stable power-GARCH processes, In: Journal of Econometrics, 2002, 106, 1, 97-107

[23] Trivedi, J., Spulbar, C., Birau, R., Mehdiabadi, A., Modelling volatility spillovers, cross-market correlation and co-movements between stock markets in European Union: an empirical case study, In: Business, Management and Economics Engineering, 2021, 19, 1, 70-90

[24] Spulbar, C., Trivedi, J., Birau, R., Investigating abnormal volatility transmission patterns between emerging and developed stock markets: a case study, In: Journal of Business Economics and Management, 2020, 21, 6, 1561-1592

[25] Gujarati, D.N., Basic Econometrics, 4th Edition, McGraw-Hill Companies, 2004

[26] Taylor, S., Modeling Financial Time Series, Wiley and Sons: New York, 1986

[27] Glosten, L.R., Jagannathan, R., Runkle, D.E., On the Relation between the Expected Value and the Volatility of the Nominal Excess Return on Stocks, In: Journal of Finance, 1993, 48, 5, 1779-1801 
[28] Spulbar, C., Birau, R., Testing weak-form efficiency and long-term causality of the R.I.P.H emerging capital markets, In: International Journal of Business Quantitative Economics and Applied Management Research, 2018, 5, 2, $1-19$

[29] Batool, M., Ghulam, H., Hayat, M.A., Naeem, M.Z., Ejaz, A., Imran, Z.A., Spulbar, C., Birau, R., Gorun, T.H., How COVID-19 has shaken the sharing economy? An analysis using Google trends data, In: Economic ResearchEkonomska Istraživanja, 2020, http://doi.org/10.1080/1331677X.2020.1863830

\section{Authors:}

ELIZABETH COKER-FARRELL ${ }^{1}$, ZULFIQAR ALI IMRAN² ${ }^{2}$ CRISTI SPULBAR ${ }^{3}$, ABDULLAH EJAZ $^{4}$, RAMONA BIRAU ${ }^{5}$, RADU CĂTĂLIN CRIVEANU 6

${ }^{1}$ Concordia University of Edmonton, Canada e-mail: elizabeth.coker-farrell@concordia.ab.ca

${ }^{2}$ Lahore Business School, University of Lahore, Pakistan e-mail: zulfiqaraliimran05@gmail.com

${ }^{3}$ Faculty of Economics and Business Administration, University of Craiova, Romania e-mail: cristi_spulbar@yahoo.com

${ }^{4}$ Bredin College of Business and Health Care, Canada e-mail: ejazabdullah03@gmail.com

${ }^{5}$ C-tin Brancusi University of Targu Jiu, Faculty of Education Science, Law and Public Administration, Romania

${ }^{6}$ Independent researcher and Associate professor, PhD e-mail: raducriv@yahoo.com

\section{Corresponding author:}

RAMONA BIRAU

e-mail: ramona.f.birau@gmail.com 